\begin{tabular}{|l|l|l|}
\hline \multicolumn{2}{|c|}{ PublisherInfo } \\
\hline \hline PublisherName & $:$ & BioMed Central \\
\hline \hline PublisherLocation & $:$ & London \\
\hline \hline PublisherImprintName & $:$ & BioMed Central \\
\hline \hline
\end{tabular}

\title{
Phosphorylation without ATP
}

\begin{tabular}{|l|l|l||}
\hline \multicolumn{2}{|c|}{ ArticleInfo } \\
\hline \hline ArticleID & $:$ & 5023 \\
\hline \hline ArticleDOI & $:$ & $10.1186 /$ gb-spotlight-20041220-01 \\
\hline \hline ArticleCitationID & $:$ & spotlight-20041220-01 \\
\hline \hline ArticleSequenceNumber & $:$ & 86 \\
\hline \hline ArticleCategory & $:$ & Research news \\
\hline ArticleFirstPage & $:$ & 1 \\
\hline \hline ArticleLastPage & $:$ & 3 \\
\hline \hline & $:$ & RegistrationDate : 2004-12-20 \\
ArticleHistory & $:$ & OnlineDate \\
\hline \hline ArticleCopyright & $:$ & BioMed Central Ltd2004-12-20 \\
\hline \hline ArticleGrants & $:$ & \\
\hline \hline ArticleContext & $:$ & 130595511 \\
\hline \hline
\end{tabular}


For the first time, scientists have described in this week's Science a way for cells to add phosphate groups to proteins that doesn't involve using adenosine triphosphate (ATP) as a donor (Science 2004, 306:2101-2105).

"Nobody had ever dreamt you could phosphorylate with a donor other than ATP," said senior author Solomon Snyder at Johns Hopkins University in Baltimore, who, along with colleagues, suggested a decade ago that inositol pyrophosphates such as diphosphoinositol pentakisphosphate (IP7) might serve as phosphorylating agents due to their highly energetic pyrophosphate bonds.

"ATP phosphorylation has heretofore been regarded as the primary mode of all cellular signaling in biology," Snyder told us. "IP7 phosphorylation may be of comparable importance, with similarities but major differences - for instance, it is nonenzymatic. It may represent a new form of intracellular signaling."

In the current study, the group synthesized IP7 and radiolabeled the putative donor pyrophosphate. As a control to ensure any apparent phosphorylation did not simply reflect binding of IP7 to proteins, the researchers also created IP7 with a different radiolabeled phosphate group.

In mouse brain and yeast extracts, gel electrophoresis and autoradiography revealed the radiolabeled IP7 phosphorylated as many proteins as radiolabeled ATP, while the control did not. "IP7 looks to act quite universally," Snyder said. "And while the numbers are similar, it looks as if IP7 and ATP are phosphorylating different proteins."

"What's also remarkable is we have evidence not just of phosphorylation of proteins, but of pyrophosphorylation, adding a phosphate on top of a phosphate. That's completely unheard of," Snyder said.

IP7 phosphorylation appears selective for eukaryotic organisms, with none seen in Escherichia coli extracts. Phosphorylation patterns also differed among mouse brain, mouse kidney, and Drosophila melanogaster. IP7 requires magnesium as a cofactor just as enzymes for ATP do.

The principal phosphoproteins IP7 phosphorylated identified via matrix-assisted laser desorption/ ionization mass spectrometry, NSR1 and SRP40, are both nucleolar proteins associated with ribosomal biogenesis. Deletion mutants of NSR1 revealed phosphorylation occurred predominantly at a region containing extensive stretches of serine residues surrounded by acidic amino acids, and a homology search of the yeast protein database revealed SRP40 had a similar region.

The primary objective now, said Stephen Shears of the National Institute of Environmental Health Sciences in Research Triangle Park, NC, is to determine whether IP7 phosphorylation has any biological significance in vivo.

"It's not going to be easy," said Shears, who did not participate in the study. "Experiments that approach the problem by changing levels of IP7 in intact cells will never be specific enough, because so many additional off-target effects will result; the inositol pyrophosphates are pleiotropic." 
"One very direct approach: Identify an IP7 target protein with a defined function that is assayable with intact cells. Then, identify an amino-acid residue on that target that is only phosphorylated by IP7 and not by other protein kinases. Several candidate IP7 targets may need to be screened," Shears told us. "Having done that, express in cells a single site mutant version of this protein that cannot be phosphorylated by IP7. This will be a kind of 'dominant negative.' Now, perform bioassays that are normally done for the protein in question and see if its function is impaired."

John Yorkof Duke University in Durham, NC, who co-wrote a commentary on Snyder's work, said future research should address what the specificity and stereochemistry of IP7 binding is, how phosphate transfer is activated, and how a target serine or phosphoserine is selected.

"It's puzzling that if you produce yeast NSR1 in bacteria as a recombinant protein, the transfer of phosphate does not occur. That suggests a priming step done by the yeast cell prior to transfer, which is a little peculiar, and requires a follow-up study to characterize," York told us.

\section{References}

1. Science, [http://www.sciencemag.org]

2. Solomon Snyder, [http://neuroscience.jhu.edu/peopledetail.asp?ID=1]

3. Purified inositol hexakisphosphate kinase is an ATP synthase: Diphosphoinositol pentakisphosphate as a high-energy phosphate donor

4. Stephen Shears, [http://dir.niehs.nih.gov/dirlst/faculty/faculty.htm]

5. John York, [http://pharmacology.mc.duke.edu/faculty/york.htm] 